\title{
Rapid Detection of Vancomycin-resistance Enterococci by SYBR Green Real-time PCR
}

\author{
Byoung-Seon Yang \\ Department of Clinical Pathology, Jinju Health College, Jinju 660-757, Korea
}

\begin{abstract}
Vancomycin-resistant Enterococci (VRE) are a leading cause of a nosocomial infection. While seven glycopeptide resistance genotypes have been found in Enterococci, vanA and $\operatorname{van} B$ are the most common resistance genotypes. Aims of this study were to detect antibiotic susceptibilities of 23 Enterococcus spp, which broke out in a university hospital by the disk diffusion test, to investigate specific genes of vanA and vanB by conventional and real-time PCR. PCR for vanA and vanB was performed on 23 Enterococci, all 23 were positive for vanA type. This study reports the validation of a simple and rapid VRE detection method that can be easily incorporated into the daily routine of a clinical laboratory. Early detection of VRE strains, including those with susceptibility to Vancomycin, is of paramount clinical importance, as it allows a rapid initiation of strict infection control practices as well as a therapeutic guidance for a confirmed infection. The real-time PCR method is a rapid technique to detect vanA in Enterococci. It is simple and reliable for the rapid characterization of VRE.
\end{abstract}

Keywords: Enterococci, vanA, vanB

This is an Open Access article distributed under the terms of the Creative Commons Attribution Non-Commercial License (http://creativecommons.org/licenses/by-nc/3.0) which permits unrestricted non-commercial use, distribution, and reproduction in any medium, provided the original work is properly cited.

Copyright (C) 2014 The Korean Society for Clinical Laboratory Science. All rights reserved.
Corresponding author: Byoung-Seon Yang Department of Clinical Pathology, Jinju Health College, Jinju 660-757, Korea Tel: 82-55-740-1851 E-mail: ybseon@hanmail.net

Received: May 29, 2014 Revised: June 16, 2014 Accepted: June 16, 2014

\section{서 론}

Enterococci는 건강한 성인의 경우 대장에 상주하는 정상 상재 균이다(Elsner 등, 2000). vancomycin-resistant enterococci (VRE)은 1987년 유럽에서 처음으로 보고된 이래 세계적으로 심내 막염, 균혈증, 비뇨기계감염과 신생아 폐혈증등의 환자에 있어서 병원내 감염으로 증가 추세에 있다(Dutka-Malen 등, 1995). Enterococcus faecalis와 E. faecium은 임상에서 가장 많이 분리 되는 종이며, E. avium, E. durans, E. casseliflavus, E. gallinarum과 E. flavescens 균주는 5\%이하로 드물게 분리된다(Papaparaskevas 등, 2002). VRE는 국내에서는 1992년 처음으로 보고 되었고 원내 감염을 일으키는 중요한 세균그룹으로 알려졌다(Cheng 등, 1997). VRE 집락이 형성된 환자는 신속히 격리하고 적어도 1 주 이 상의 간격으로 시행한 감시배양에서 연속적으로 3회 음성인 경우 격리를 해지한다. VRE의 정확하고 신속한 검출은 병원 내 감염전 파의 추적과 관리를 위해서 필요하다. 또한 VRE가 분리되는 환자 에 있어서 장내 집락화의 유무를 신속하게 검출하여 사람간의 전파
방지를 해야 한다(Devriese 등, 1993). Vancomycin내성 유전자 는 Enterococcus 종사이에 전이가 가능하고, VRE검출이 지연되 면 균주가 집락화 되어 병원감염의 문제가 된다. 전통적인 항생제 감수성 검사법 의한 VRE검출은 1 일에서 5 일정도 소요되며 $\operatorname{van}$ 유 전형 구별이 안되고 저농도 glycopeptide내성세균 검출이 어렵다 (Elsner 등, 2000). 현재 VRE균주를 분자유전학적 방법으로 직접 검출하는 방법이 많이 사용하고 있다. PCR방법은 임상에서 분리한 균주의 검출 및 항생제내성유전자 분석에 특이적이고, 시간적인 소 모가 적고 분석력과 재현성이 좋은 방법이다(Monstein 등, 1998). SYBR Green real-time PCR방법 melting curve 분석은 1997년 처음으로 소개 되었고 두가닥의 핵산이 한가닥으로 분리되는 현상 을 말한다. 두가닥의 DNA에 비특이적으로 결합하는 형광색소인 SYBR Green을 사용하여 융해과정이 실시간으로 측정된다. 반응 산물의 염기서열, 크기 및 $\mathrm{GC}$ 비율에 따라 특징적인 melting curve 을 보여 전기영동 하지 않고 반응산물을 확인할 수 있다(Tripathi 등, 2013). 본 연구에서는 대학병원으로부터 VRE균주를 분리하여 항생제감수성 검사를 실시하고 일반PCR 및 real-time PCR 방법 
을 실시하여 신속검출의 유용성을 평가 하였다.

\section{재료 및 방법}

\section{1. 사용균주}

대학병원에서 VITEK II (bioMerieux, Inc. Haxelwood, MO, USA)기기로 vancomycin-resistance enterococci 세균으로 동 정된 23균주를 대상으로 하였다.

분리균주 동정 및 항생제 감수성 검사 정도관리 균주로 Enterococcus faecium ATCC 19434 균주를 사용하였다.

\section{2. 방법}

\section{1) Enterococcus종 동정}

세균 부유액을 혈액한천배지에 접종한 후 $30^{\circ} \mathrm{C}$ 배양기에서 18 24시간 배양 후 집락 및 용혈유무를 관찰하였다, 순수분리집락 을 도말하여 그람염색을 실시하였다. 생화학적 시험으로 catalase test, bile esculin test, arabinose분해, $6.5 \% \mathrm{NaCl}$ 배지에서 성장 유무를 관찰하였다.

\section{2) 항생제감수성 시험}

세균 부유액을 Mueller-Hinton Agar (MHA)에 고르게 접종한 후, 배지의 중앙에는 vancomycin $(30 \mu \mathrm{g})$ 디스크와 teicoplanin $(30 \mu \mathrm{g})$ 있는 디스크를 $20 \mathrm{~mm}$ 간격으로 놓았다. 접종 배지는 $37^{\circ} \mathrm{C}$ 항온기에 18 시간 배양 후 결과를 판정하였다.

\section{3) 균주로 부터의 DNA 분리}

23 개의 VRE 균주를 가온법을 이용하여 DNA를 추출하였다. 순 수 분리된 23 개 균주를 $90^{\circ} \mathrm{C}$ 에서 10 분방치 후 진탕 하였다. 그리고 $13,000 \mathrm{rpm}$ 서 5 분간 원심 후 상층액을 얻었다.

\section{4) $P C R$ 을 위한 Primer의 합성}

Glycopeptide내성유전자 ( $\operatorname{van} A$, $\operatorname{van} B)$ 검출부위로 하는 primer 을 제작하였고 각 primer의 염기서열, 반응산물을 크는 Table 1 과 같다.

Table 1. PCR primers used in this study

\begin{tabular}{ccc}
\hline Primer & Sequence & $\begin{array}{c}\text { Product } \\
\text { length (bp) }\end{array}$ \\
\hline van gene & & \\
van AB-F & GTA GGC TGC GAT ATT CAA AGC & \\
van A-R & CGA TTC AAT TGC GTA GTC CAA & 231 \\
van B-R & GCC GAC AAT CAA ATC ATC CTC & 330 \\
\hline
\end{tabular}

5) $P C R$

$\mathrm{PCR}$ 을 위한 PCR 혼합액 $\mathrm{dNTP}(2.5 \mathrm{mM}), 10 \times \mathrm{PCR}$ buffer 2 $\mu \mathrm{L}$, primer $10 \mathrm{pmol}$ 각각 $1 \mu \mathrm{L}$ 씩 넣었고, genomic DNA $(25 \mu \mathrm{g})$ $1 \mu \mathrm{L}$, TaqDNA polymerase (2 unit) $1 \mu \mathrm{L}$, 최종 반응액은 증류수 로 $20 \mu \mathrm{L}$ 되게끔 실시하였다. DNA thermal cycler (Perkin Elmer, Inc. Wellesley, $\mathrm{MA}, \mathrm{USA}$ )에서 $\operatorname{Van}$ 유전자 검출은 $95^{\circ} \mathrm{C}$ 에서 1 분 간 변성, $64^{\circ} \mathrm{C}$ 에서 2 분간 접합, $72^{\circ} \mathrm{C}$ 에서 1 분 30 초간 확장의 순서 로 35 회를 시행하고 $72^{\circ} \mathrm{C}$ 에서 7 분간 최종확장 하였다. $\mathrm{PCR}$ 증폭 산물을 $1.5 \%$ agarose gel에 midori green $(2 \mu \mathrm{L})$ 을 넣어 $1 \times \mathrm{TAE}$ buffer에서 70 volt, $100 \mathrm{~mA}$ 로 45분 동안 전기영동을 실시한 다음, agarose gel을 UV transilluminator로 관찰하고, Gel Doc (Bio-Red, Inc. Hercules, CA, USA)이미지 분석장치로 사진 촬영 하였다.

6) Real-time $P C R$

iQ SYBR Green Supermix (Bio-Rad Laboratories, Inc., Hercules, CA, USA)을 사용하여 real-time PCR을 실시하였다. 10 $\mu \mathrm{L}$ 의 iQ SYBR Green Supermix, $2 \mu \mathrm{L}$ 의 primer혼합액, $1 \mu \mathrm{L}$ 의 $\mathrm{DNA}, 7 \mu \mathrm{L}$ 의 멸균증류수 넣어 반응액 $20 \mu \mathrm{L}$ 를 제조하여 real-time PCR을 실시하였다. Real-time PCR은 CFX96 real-time PCR system (Bio-Rad Laboratories, Inc., Hercules, CA, USA)를 이용 하였다. $95^{\circ} \mathrm{C}$ 에서 3 분 반응 후 $95^{\circ} \mathrm{C}$ 에서 10 초, $60^{\circ} \mathrm{C}$ 에서 10 초, $72^{\circ} \mathrm{C}$ 에서 20 초에서 반응을 40 회 반복하였다. 마지막에서 $\mathrm{PCR}$ 반 응이 끝난 후 $65^{\circ} \mathrm{C}$ 에서 $95^{\circ} \mathrm{C}$ 까지 초당 0.5 의 속도로 온도를 증가시 키면서 융해곡선을 분석하였다.

\section{결 과}

\section{Enterococcus 종 동정}

혈액한천배지에서 다양한 용혈양상을 보이고, 그람염색결과 그 람양성 쌍알균, 사슬알균형태로 나타났다. 생화학적 시험결과 catalase음성, bile esculin양성, $6.5 \% \mathrm{NaCl}$ 에서 성장하였고 arabinose을 분해하여 E. faecium으로 동정하였다.

\section{2. 항생제감수성 시험}

디스크감수성 시험에서는 vancomycin 디스크에서는 1 23균 주(100\%)가 내성으로 나타났으며, 또한 teicoplanin 디스크에 모 든 균주가 내성으로 나타났다(Table 2).

\section{3. $\mathrm{PCR}$ 및 real-time $\mathrm{PCR}$}

일반 PCR에서 vanA 생성 Enterococcus균주는 23균주(100\%) 
Table 2. Distribution of 23 strains of VRE from university hospital isolates, susceptibility profile and genotype

\begin{tabular}{lccccc}
\hline & \multicolumn{2}{c}{ Disk diffusion } & & \multicolumn{2}{c}{ PCR } \\
\cline { 2 - 3 } \cline { 5 - 5 } Strains & Van & TeC & & VanA & VanB \\
\hline CHN1 & $\mathrm{R}$ & $\mathrm{R}$ & + & - \\
CHN2 & $\mathrm{R}$ & $\mathrm{R}$ & + & - \\
CHN3 & $\mathrm{R}$ & $\mathrm{R}$ & + & - \\
CHN4 & $\mathrm{R}$ & $\mathrm{R}$ & + & - \\
CHN5 & $\mathrm{R}$ & $\mathrm{R}$ & + & - \\
CHN6 & $\mathrm{R}$ & $\mathrm{R}$ & + & - \\
CHN7 & $\mathrm{R}$ & $\mathrm{R}$ & + & - \\
CHN8 & $\mathrm{R}$ & $\mathrm{R}$ & + & - \\
CHN9 & $\mathrm{R}$ & $\mathrm{R}$ & + & - \\
CHN10 & $\mathrm{R}$ & $\mathrm{R}$ & + & - \\
CHN11 & $\mathrm{R}$ & $\mathrm{R}$ & + & - \\
CHN12 & $\mathrm{R}$ & $\mathrm{R}$ & + & - \\
CHN13 & $\mathrm{R}$ & $\mathrm{R}$ & + & - \\
CHN14 & $\mathrm{R}$ & $\mathrm{R}$ & + & - \\
CHN15 & $\mathrm{R}$ & $\mathrm{R}$ & + & - \\
CHN16 & $\mathrm{R}$ & $\mathrm{R}$ & + & - \\
CHN17 & $\mathrm{R}$ & $\mathrm{R}$ & + & - \\
CHN18 & $\mathrm{R}$ & $\mathrm{R}$ & + & - \\
CHN19 & $\mathrm{R}$ & $\mathrm{R}$ & + & - \\
CHN20 & $\mathrm{R}$ & $\mathrm{R}$ & + & - \\
CHN21 & $\mathrm{R}$ & $\mathrm{R}$ & + & - \\
CHN22 & $\mathrm{R}$ & $\mathrm{R}$ & + & - \\
CHN23 & $\mathrm{R}$ & $\mathrm{R}$ & + & - \\
\hline Van & H & + & + \\
\hline
\end{tabular}

Van, vancomycin; Tec, teicoplanin; $R$, resistance.

가 양성으로 나타났으며, vanB생성 Enterococcus균주는 검출되 지 않았다. Real-Time PCR 분석 결과 23균주가 양성(melt peak $80.50^{\circ} \mathrm{C}$ )으로 나타나 일반 PCR결과와 일치하였다(Table 2, Fig. 1).

\section{고 찰}

Enterococci는 사람뿐만 아니라 동물, 식품으로부터 분리된다. 항생제 내성인 vancomycin-resistant enterococci (VRE)균주가 증가 추세에 있다. VRE균주는 병원내 감염을 일으키고 중환자실이 나 혈액종양병동 등에서 토착화되어 가고 있는 실정이다. VRE규주 의 유행과 전파를 막기 위한 감염관리지침이 있으나 모든 병원에서 적용하기가 어려운 실정이고 다각적 감염관리를 시행하여도 근절 하기 힘든 병원감염의 주요 다제내성균이다(Facklam 등, 1989). VRE는 다양한 항생제에 저항성을 나타내고, 5 종의 내성유전자는 $\operatorname{van} A, \operatorname{van} B, \operatorname{van} D, \operatorname{van} E$ 그리고 $\operatorname{van} G$ 로 획득유전자이다. $\operatorname{van} C 1$, $\operatorname{van} C 2 / C 32$ 종의 유전자는 내인성유전자이다. $\operatorname{van} A$ 와 $\operatorname{van} B$ 유전 자을 가진 VRE가 임상에서 가장 많이 분리된다(Gold, 2000). VRE 유전자는 접합성 plasmid나 transposon에 위치한다(Radu 등,

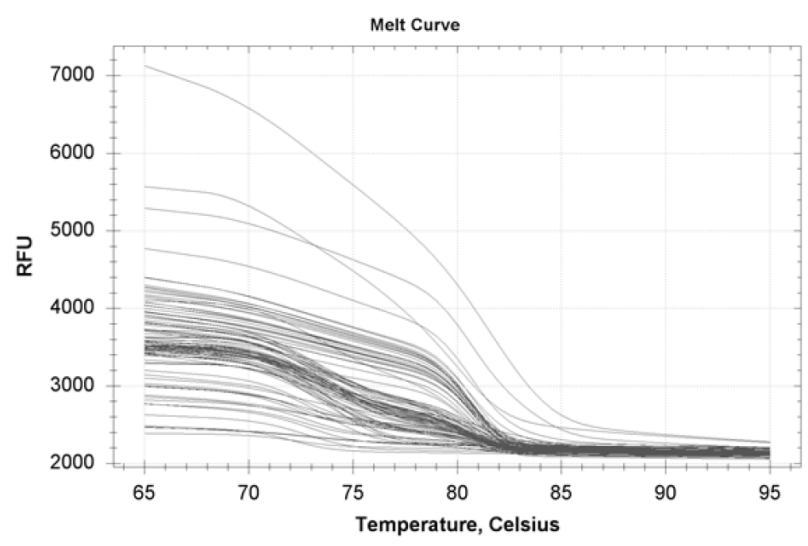

Fig. 1. Amplification melting curves for VRE in vanA real-time PCR.

2001). vanA 유전자를 가진 Enterococci는 vancomycin과 teicoplanin의 고농도에 저항성을 보이고 $\operatorname{van} B$ 의 경우는 vancomycin만 내성을 보인다. vanC의 경우는 vancomycin의 저 농도에 내성을 보인다(Bell 등, 1998).

VRE전파는 균주 자체가 이동하는 수직 전이와 내성 유전자만이 전파되는 수평 전이 기전에 의하며, VRE 전파를 방지하기 위하여 대부분의 대학병원에서는 centers for disease control and prevention $(\mathrm{CDC})$ 의 hospital infection control practices advisory committee (HICPAC)기준에 따르고 있다.

본 실험에서 표현형적 방법으로 분리된 VRE 23균주를 디스크 감수성 시험 결과 모든 균주가 내성으로 나타났다. PCR방법에서 vanA 생성 Enterococcus균주는 23균주(100\%)가 양성으로 나타 났으며, vanB 생성 Enterococcus균주는 검출되지 않았다. vanA 생성 E. faecium에 의한 병원내 집단 발병시 직장도말 검체를 액체 배지에서 증균시킨 후 $\operatorname{van} A$ 에 특이한 PCR로 확인 하는 방법은 24 30시간 내에 $95 \%$ 의 민감도와 $100 \%$ 의 특이도를 보여 평균 3 5 일이 걸리는 배양법의 민감도 및 특이도와 비교할 때 우수하다고 하였다(Roger 등, 1999; Sloan 등, 2004). 또한 Kim 등(2007)도 내 부 대조물질을 사용하여 위음성을 확인하고, 선택 액체배지를 이용 한 신속 PCR을 시행하는 것이 VRE 보균 여부를 감시하는데 빠르고 민감한 방법이라고 하였지만 vanA 이외에 다른 유전자형을 검출 하려면 다중PCR을 시행해야 하며 민감도가 떨어질 가능성이 있다 고 하였다.

본연구에 사용한 Enterococcus spp. 균주에서는 $\operatorname{VanA}$ 유전자 를 포함하고 있는 것으로 나타났으며 PCR 방법은 $\operatorname{van} A, \operatorname{van} B$ 유 전자의 검출과 이 유전자의 monitoring에 중요한 역할을 할 것이 다. 따라서 real-time PCR방법은 VRE균주를 정확하고 신속하게 검출할 수 있어 원내감염의 감시배양에 유용한 방법이라 사료된다. 
Acknowledgements: None

Funding: 본 연구는 2013학년도 진주보건대학교 연구비지원에 의하여 이루어 졌음.

Conflict of interest: None

\section{References}

1. Bell JM, Paton JC, Turnidge J. Emergence of vancomycin-resistant enterococci in Australia: phenotypic and genotypic characteristics of isolates. J Clin Microbiol. 1998, 36:2187-2190.

2. Cheng S, McCleskey FK, Lin M, Gress HJ, Petroziello JM, Lin R, et al. A PCR assay for identification of Enterococcus faecium. $J$ Clin Microbiol. 1997, 35:1248-1250.

3. Devriese LA, Pot B, Collins MD. Phenotypic identification of the genus Enterococcus and differentiation of phylogenetically distinct enterococcal species and species groups. J Bacteriol. 1993, 75:399-408.

4. Dutka-Malen S, Evers S, Courvalin P. Detection of glycopeptide resistance genotypes and identification to the species level of clinically relevant enterococci by PCR. J Clin Microbiol. 1995, 33:24-27.

5. Elsner HA, Sobottka I, Feucht HH, Harps E, Haun C, Mack D, et al. Nosocomial outbreak of vancomycin-resistant Enterococcus faecium at a German university pediatric hospital. Int J Hyg Envir Heal. 2000, 203:147-152.

6. Facklam RR, Collins MD. Identification of Enterococcus species isolated from human infections by a conventional test scheme. J Ind Microbiol 1989, 27:731-734.

7. Gold HS. Vancomycin-resistant enterococci: Mechanisms and clinical observations. Clin Infect Dis. 2001, 33:210-219.

8. Kim S. Sung H, Jeon HS, Park SJ, Park SH, Kim MN. Evaluation of a rapid enrichment-PCR method for the detection of vanA vancomycin-resistant enterococci in fecal specimens. Korean J Clin Microbiol. 2007, 10:44-48.

9. Monstein HJ, Quednau M, Samuelsson A, Ahrne S, Isaksson B, Jonasson J. Division of the genus Enterococcus into species groups using PCR-based molecular typing methods. Microbiology. 1998, 144:1171-1179.

10. Papaparaskevas J, Tassios PT, Kalapothaki V, Avlami A, Legakis NJ, Vatopoulos AC. Epidemiology of multiresistant Enterococcus avium isolates in a Greek tertiary care hospital. Int. J Antimicrob Agents. 2002, 20:432-437.

11. Roger M, Faucher MC, Forest P, St-Antoine P, Couttlee F. Evaluation of vanA-specific PCR assay for detection of vancomycin-resistant Enterococcus faecium during a hospital outbreak. J Clin Micorbiol. 1999, 37:3348-3349.

12. Sloan LM. Uhl JR, Vetter EA, Schleck CD, Harmsen WS, Manahan J, et al. Comparison of the Roche LightCycler vanA/vanB detection assay and culture for detection of vancomycin-resistant enterococci from perianal swabs. I Clin Microbiol. 2004: 42:2636-2643.

13. Tripathi A, Shukla SK, Singh A, Prasad KN. A new approach of real-time polymerase chain reaction in detection of vancomycin-resistant enterococci and its comparison with other methods. IJ Med Micro. 2013, 31:47-52. 